\title{
Morphology and vascularization of the corpus luteum of peccaries (Pecari tajacu, Linnaeus, 1758) throughout the estrous cycle
}

\author{
[Morfologia e vascularização do corpo lúteo de catetos (Pecari tajacu, Linnaeus, 1758) \\ ao longo do ciclo estral] \\ M.T.M. Miranda-Moura ${ }^{1}$, G.B. Oliveira ${ }^{1}$, G.C.X.Peixoto ${ }^{1}$, J.M. Pessoa ${ }^{3}$, P.C. Papa ${ }^{2}$, \\ M.S. Maia ${ }^{4}$, C.E.B. Moura ${ }^{1}$, M.F. Oliveira ${ }^{1 *}$ \\ ${ }^{1}$ Universidade Federal Rural do Semiárido - UFERSA - Mossoró, RN \\ ${ }^{2}$ Faculdade de Medicina Veterinária e Zootecnia - FMVZ-USP - São Paulo, SP \\ ${ }^{3}$ Universidade Federal do Rio Grande do Norte - UFRN - Natal, RN \\ ${ }^{4}$ Empresa de Pesquisa Agropecuária do Rio Grande do Norte - EMPARN - Natal, RN
}

\begin{abstract}
The current paper characterizes the changes in morphology and vascularization of the corpus luteum of collared peccaries during the estrous cycle and correlates progesterone synthesis $\left(\mathrm{P}_{4}\right)$. Twenty females were subjected to a treatment for estrus synchronization; an ear implant containing $1.5 \mathrm{mg}$ of norgestomet was implanted on D0, whereas on D9 the peccaries received an IM injection of eCG 200UI and 50g of PGF2a. The animals were divided into four groups (G1, G2, G3 and G4) and euthanized on postovulation days $3,12,18$ and 22. The ovaries were collected and the corpora lutea were measured and processed for histological and vascular density (Dv). Blood was collected for dosage of $\mathrm{P}_{4}$ serum. The morphology of the ovaries, the corpora lutea and $\mathrm{P}_{4}$ varied significantly during the estrous cycle $(\mathrm{P}<0.001)$. There was a significant co-relationship between weight and length of the ovaries and CL $(\mathrm{r}=$ $0.66, r=0.52, \mathrm{P}<0.05$, respectively) and between weight, length and width of the $\mathrm{CL}$ and $\mathrm{P}_{4}(\mathrm{r}=0.51, \mathrm{r}=$ 0.54 and $\mathrm{r}=0.68, \mathrm{P}<0.05$, respectively). The luteal Dv was highly influenced by the estrous cycle phase $(\mathrm{P}<0.0001)$. The $\mathrm{P}_{4}$ and luteal Dv concentrations were higher in $\mathrm{G} 2$ and evidenced maximum secretory activity, with a highly significant correlation $(\mathrm{P}<0.0001)$. Assessed lutein parameters may estimate the phase of the estrous cycle in peccaries and the functional activity of the corpus luteum.
\end{abstract}

Keywords: collared peccary, corpora lutea, estrous cycle, progesterone, vascular density

\section{RESUMO}

Objetivou-se caracterizar as variações na morfologia e vascularização do corpo lúteo (CL) de catetos durante ciclo estral (CE) e correlacioná-las com a concentração de progesterona (P4). Vinte fêmeas de cateto foram submetidas a tratamento de sincronização do estro; no D0 receberam implante auricular

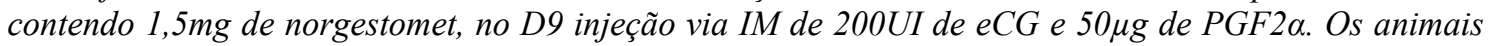
foram divididos em quatro grupos (G1, G2, G3 e G4) e eutanasiados nos dias três, 12, 18 e 22 pósovulação. Os ovários foram coletados e os CL foram mensurados e processados para avaliação histológica e da densidade vascular (Dv). O sangue foi coletado para dosagem da P4 sérica. A morfologia dos ovários, $C L$ e a concentração de P4 variaram significativamente durante o $C E$ $(P<0,001)$. Houve correlação significativa entre peso e comprimento dos ovários e $C L(r=0,66, r=$ $0,52, P<0,05$, respectivamente) e entre peso, comprimento e largura do $C L$ e a concentração de $P 4$ $(r=0,51, r=0,54$ e $r=0,68 ; P<0,05$, respectivamente). A Dv do CL se mostrou muito influenciada pela fase do CE $(P<0,001)$ e apresentou alta correlação significativa $(P<0,001)$. No G2 os maiores valores de $P 4$ e Dv confirmaram máxima atividade secretória do $C L$ nesse estádio. Os parâmetros luteínicos avaliados podem ser usados para estimar a fase do ciclo estral em catetos e a atividade funcional do $C L$.

Palavras-chave: cateto, corpo lúteo, ciclo estral, progesterona, densidade vascular

Recebido em 2 de junho de 2015

Aceito em 16 de setembro de 2015

*Autor para correspondência (corresponding author)

E-mail: moacir@ufersa.edu.br 


\section{INTRODUCTION}

The collared peccary (Pecari tajacu), an ungulate mammal found throughout the American continent, may be underscored among wild animals for its scientific potential (Nowak and Paradiso, 1983). Knowledge on the reproduction parameters of the species is highly relevant since commercial breeding is on the increase in Brazil and data may be used in future reproduction biotechniques. Little data on the reproduction of peccaries is available in the literature. Most research works are old publications and fail to give the precise conditions of the animals in the semi-arid habitat.

The morphometry of the reproduction organs is very important since variations reflect the dynamic characteristics of the ovary structure causing the organ's gametogenic and esteroidogenic functions. When the estrous cycle is established, the number and size of the follicles in the ovaries vary throughout the period. The ovary's morphological characteristics may be employed to verify pathologies such as cysts and tumors, to determine the cyclic lutein ovarian activity and even to assess the cycle's probable phase, with the possible inference on the animal's fertility (Nascimento et al., 2003).

The corpus luteum (CL) is a transitory endocrine gland formed on the wall of the Graafian follicle after ovulation by a complex mechanism that involves biochemical and morphological changes, variety in size, structure and steroidogenic activity at different stages of the estrous cycle and pregnancy, with a special function to secrete the progesterone. Progesterone has many functions in the female reproduction system, such as the regulation of the duration of the estrous cycle, the relaxing of the myometrium, the stimulation of the proliferation of endometrial cells and the maintenance of conditions in the uterus for the development of the fetus (Bertan et al., 2006).

The normal development of the corpus luteum and its capability in producing progesterone, growth factors, angiogenic factors and vasoactive compounds depend on its vascularization and blood supply (Acosta and Miyamoto, 2004), although the vascular endothelial growth factor (VEGF) and the basic fibroblast growth factor
(bFGF) are the main causes for the development and maintenance of the dense network of neoformed capillaries. Furthermore, they also contribute in a paracrine and autocrine way in the production of progesterone (Needle et al., 2007). Current analysis characterizes the structural variations of the peccaries' corpus luteum, especially those related to the organ's vascularization and its function in the synthesis of progesterone.

\section{MATERIALS AND METHODS}

The experiment was performed at the Center for the Multiplication of Wild Animals (CEMAS) in Mossoró RN Brazil, registered at IBAMA as a scientific breeding site (n. 1478912). Twenty female peccaries with a good reproduction history were divided into four groups $(n=5$ in each group). After hormonal treatment they were euthanized on day 3,12, 18 and 22 postovulation (p.o.) to analyze the corpus luteum respectively at the early, mature, early and late regression phases. The experiment was approved by the Committee for Ethics in Animal Use of UFERSA (23091.003179/2011-41).

The animals underwent estrum synchronization protocol to obtain CLs at different phases, following Nascimento et al. (2009). Protocol was comprised of the application of an ear implant with $1.5 \mathrm{mg}$ norgestomet (CRESTAR ${ }^{\circledR}$, Intervet). Treatment lasted 11 days. On the ninth day all the females received 200UI eCG (Novormon ${ }^{\circledR}$, Syntex S.A.) and 50g PGF2 $\alpha$ (Prolise $^{\circledR}$, Arsa S.R.L.) via IM. Initial estrum signs were detected 12 hours after the removal of the progestogens. The animals, controlled by a net and placed on their back so that the trans-abdominal ultrasonography could be performed, were ultrasonographed to measure the ovaries and the corpora lutea at each phase of the estrous cycle by Aquila Vet (Pie Medical ${ }^{\circledR}$, Nutricell, Campinas, Brazil) with a multifrequential and microconvex transducer at $8 \mathrm{MHz}$ frequency.

The animals were euthanized and the ovaries immediately removed and kept in ice. All the ovaries and the corpora lutea were dissected and their length, width and weight taken. Length and width were determined by calipers and weight was taken by precision scale (Marte MOD. AL 500), taking into account the organs' symmetry. The volume of the luteal tissue was calculated by 
the ellipsis area defined by the greater and smaller diameter of the CL (Mayor et al., 2006a). Blood samples, collected by puncturing the cephalic vein, were taken to the laboratory at a temperature of $5^{\circ} \mathrm{C}$, centrifuged $(4000 \mathrm{rpm} \mathrm{x}$ $5 \mathrm{~min}$, at $5^{\circ} \mathrm{C}$ ); blood serum obtained was conserved at $-20^{\circ} \mathrm{C}$ until the progesterone tests could be performed.

The CL were dissected and cut into $0.5 \mathrm{~cm}$ wide pieces, fixed in formaldehyde $10 \%$ in a buffer phosphate solution, pH 7.2 (PBS), for 24 hours. They were then histologically processed, stained by hematoxylin-eosin and periodic acid of Schiff (PAS) and fixed between the lamina and the laminule to measure their vascular density (Dv).

After the histological procedures, six histological sections of CL from each female peccary were analyzed to quantify the sterologic parameters of the vascular density mentioned below. The test system of the cycloid arc type overlaid the images of the cuts. This system was chosen to break with the anisotropy of the organ, an essential prerequisite for the application of stereological methods in biological tissues (Peréz-Olvera et al., 2012). The test system overlaid the histological image with software Image Pro-plus. Its small axis was placed parallel to the vertical axis of the histological cut. The system comprised 35 cycloid arcs with a total length $(1 / \mathrm{p})$ of $10.4 \mu \mathrm{m}$ and 70 test points. The analysis field was limited by a test area $\left(\mathrm{A}_{\mathrm{T}}\right)$ $14.040 \mu \mathrm{m}^{2}$ by inclusion (upper and right margins) and exclusion (lower and left margins) lines. Only the profiles or vessels within the test area and which did not touch the exclusion lines were counted. The sterologic parameter of vascular density (Dv) evaluated comprised volume density (Vv) following Gaytan et al. (1999). All the (arteriole, venule and capillary) vessels in the luteinic tissue were equally evaluated without distinction.

Progesterone concentration of the blood serum was assessed by radioimmunoassay with a commercial kit (DSL-3400®, Diagnostic Systems Laboratories, U.S.A.). Standard curve was obtained by increasing concentrations of $\mathrm{P}_{4}$ (3.9062 to $1000 \mathrm{pg} / 100 \mu \mathrm{L}$ ) in a phosphate buffer with gelatin (PBS-G) made from a solution of $\mathrm{P}_{4}$ in ethanol. Radioactive progesterone [I-125] was diluted at $70 \%$ in PBS-G, whilst the primary antibody against the progesterone (from the rabbit) and the precipitation liquid (from the goat) were diluted at $60 \%$ in PBS-G. For assay control, samples of follicle fluids diluted at 1:10 in PBS-G were employed at previously dosed low, medium and high progesterone concentrations. Progesterone concentrations in the samples were calculated with the Riasmart program of the gamma radiation counter. Doses were initially given in pg per tube; concentration in $\eta \mathrm{g} / \mathrm{ml}$ was obtained after division by 100 .

Results were given as mean \pm standard deviation. Statistical analyses were performed by ANOVA followed by Tukey-Kramer's multiple comparison test and rates $\mathrm{P} \leq 0.05$ determined differences between means. The co-relationships between the size of the ovary and CL and between vascular density and progesterone were analyzed by Pearson's correlation coefficient.

\section{RESULTS}

The peccary's ovaries had the form of a bunch of grapes due to the several corpora lutea on the surface of the ovaries (Figure 1). There was no apparent change in color among the groups. Table 1 shows the morphometry results of the ovaries throughout the estrous cycle.

Table 1. Morphometry of peccary ovaries throughout the estrous cycle. Mossoró, RN, Brazil, 2015

\begin{tabular}{ccccccc}
\hline \multicolumn{3}{c}{ Right ovary } \\
\hline $\mathrm{G}$ & $\begin{array}{c}\text { Weight } \\
(\mathrm{g})\end{array}$ & $\begin{array}{c}\text { Length } \\
(\mathrm{mm})\end{array}$ & $\begin{array}{c}\text { Width } \\
(\mathrm{mm})\end{array}$ & $\begin{array}{c}\text { Weight } \\
(\mathrm{g})\end{array}$ & $\begin{array}{c}\text { Length } \\
(\mathrm{mm})\end{array}$ & $\begin{array}{c}\text { Width } \\
(\mathrm{mm})\end{array}$ \\
\hline 1 & $2.77 \pm 0.52 \mathrm{~A}$ & $22.79 \pm 1.60 \mathrm{~A}$ & $22.69 \pm 2.93$ & $2.05 \pm 0.61 \mathrm{~A}$ & $22.17 \pm 4.72$ & $17.59 \pm 2.71 \mathrm{~A}$ \\
2 & $4.62 \pm 1.11 \mathrm{~B}$ & $27.27 \pm 3.44 \mathrm{~B}$ & $17.41 \pm 3.92$ & $4.39 \pm 1.24 \mathrm{~B}$ & $19.86 \pm 3.91$ & $21.19 \pm 2.94 \mathrm{~B}$ \\
3 & $2.36 \pm 0.55 \mathrm{AC}$ & $20.43 \pm 1.24 \mathrm{AC}$ & $17.21 \pm 2.24$ & $2.35 \pm 0.78 \mathrm{AC}$ & $20.19 \pm 3.20$ & $17.06 \pm 3.67 \mathrm{BC}$ \\
4 & $1.51 \pm 0.21 \mathrm{CD}$ & $14.88 \pm 2.40 \mathrm{D}$ & $13.37 \pm 0.51$ & $1.94 \pm 0.58 \mathrm{ACD}$ & $16.68 \pm 3.73$ & $13.68 \pm 1.86 \mathrm{BCD}$ \\
\hline $\mathrm{G}=$ group. A-D indicate statistical difference, $\mathrm{P}<0.001$
\end{tabular}

$\mathrm{G}=$ group. A-D indicate statistical difference, $\mathrm{P}<0.001$ 

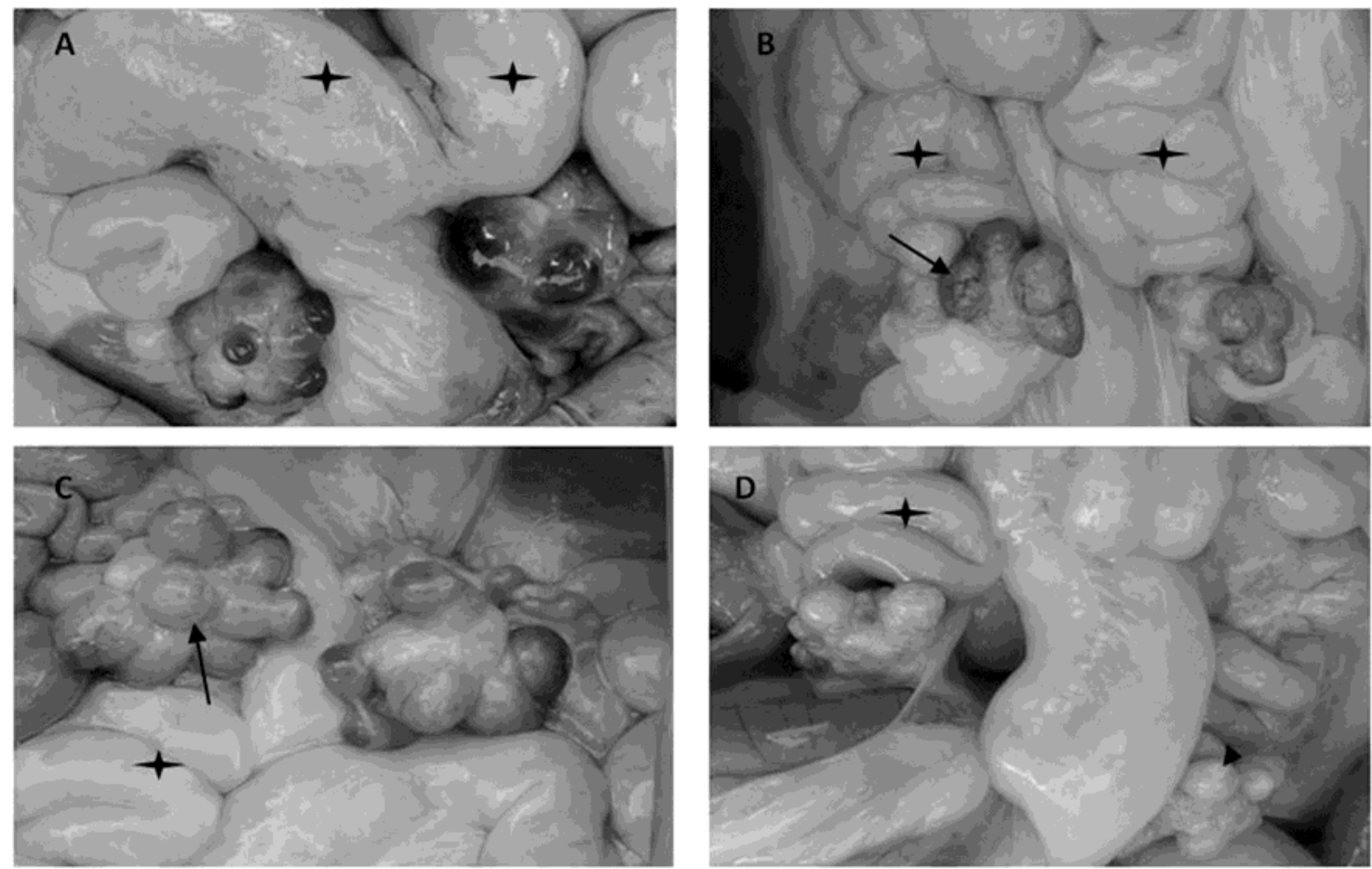

Figure 1. Peccaries' corpora lutea throughout the estrous cycle. A - CL of group 1 in dark maroon or brown; B - Group 2: intense vascularization on the surface $(\rightarrow)$. C - Group 3, the CL has a pale color; D - Group 4, CL has a whitish color $(\bullet)$. Convoluted uterine horns $(+)$.

Ovary parameters revealed changes throughout the estrous cycle due to the modifications that the corpus luteum caused in the organ, proved by a significant co-relationship between the weight and length of the ovaries and the corpora lutea $(\mathrm{r}=0.66, \mathrm{p}=0.0019 ; \mathrm{r}=0.52, \mathrm{p}=0.0191$, respectively). Group 2 (12 days p.o., or rather, the period in which the corpora lutea were mature) had the greatest weight in the two ovaries.

Table 2 demonstrates total average number of corpora lutea and for each ovary in the animals. Since there was no significant difference of these variables with regard to the groups $(p=0.2561)$, the number of ovulations in the right and left ovaries did not differ significantly.

Table 2. Mean number of corpora lutea in peccary ovaries throughout the estrous cycle. Mossoró, RN, Brazil, 2015

\begin{tabular}{cccc}
\hline & Right ovary & Left ovary & Total CL \\
\hline Group 1 & $3.75 \pm 2.06$ & $5.50 \pm 0.70$ & $7.60 \pm 4.83$ \\
Group 2 & $5.33 \pm 2.50$ & $5.33 \pm 2.08$ & $10.60 \pm 4.34$ \\
Group 3 & $2.00 \pm 1.41$ & $3.00 \pm 1.82$ & $5.60 \pm 2.61$ \\
Group 4 & $4.33 \pm 1.15$ & $3.33 \pm 2.08$ & $7.60 \pm 2.88$ \\
\hline
\end{tabular}

One corpus luteum was randomly selected from each animal to calculate weight, length and width. The peccary's CL revealed growth shown by the three-fold increase in weight between Groups 1 and 2 and by the $46 \%$ drastic decrease between Groups 2 and 4 and an evident morphological regression in Group 4. The structural parameters of the corpus luteum throughout the estrous cycle were evidenced by measurements obtained from ultrasonograph tests (Figure 2) and by calipers (Table 3 ). The peccary's ovaries had hypoechogenic, rounded and well-limited structures, with hypoechoic and irregular margins, with a circular structure at the hyperechoic center corresponding to the CL. 

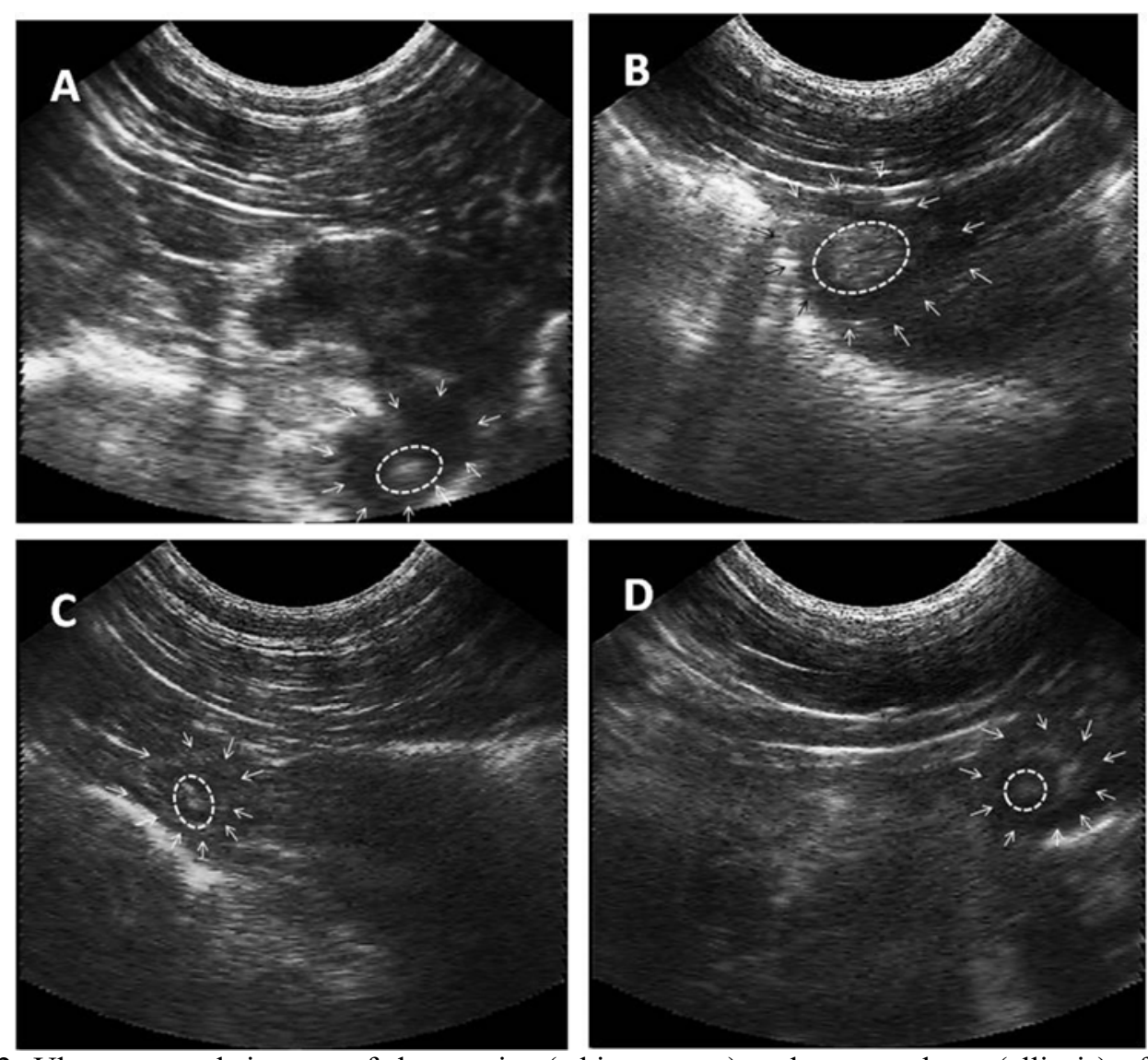

Figure 2. Ultrasonograph images of the ovaries (white arrows) and corpora lutea (ellipsis) of peccary females through the estrous cycle. (A) - Group 1, (B) - Group 2, (C) - Group 3 and (D) - Group 4.

Table 3. Structural parameters of corpora lutea in peccary ovaries throughout the estrous cycle. Mossoró, RN, Brazil, 2015

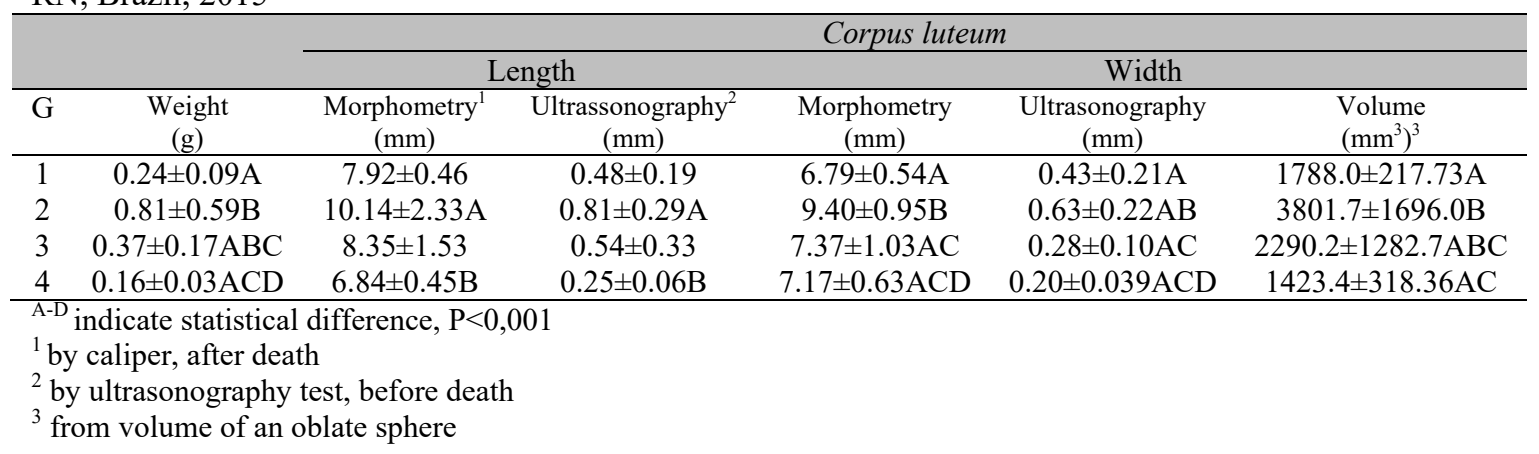

CL microscopy revealed a highly vascularized lobular organ enveloped in a capsule of conjunctive tissue. Two cell types were detected, featuring characteristics which indicated steroidogenic activity. Type 1 cell, called large luteal cell (LLC), was more abundant and bigger, with vacuolized cytoplasm and euchromatic nucleus with nucleolus. Type II cell, called small luteal cell (SLC), was smaller and somewhat rarer, with less vacuolized cytoplasm and a heterochromatic nucleus. Figure 3 shows that microscopy of CL varied throughout the estrous cycle. 

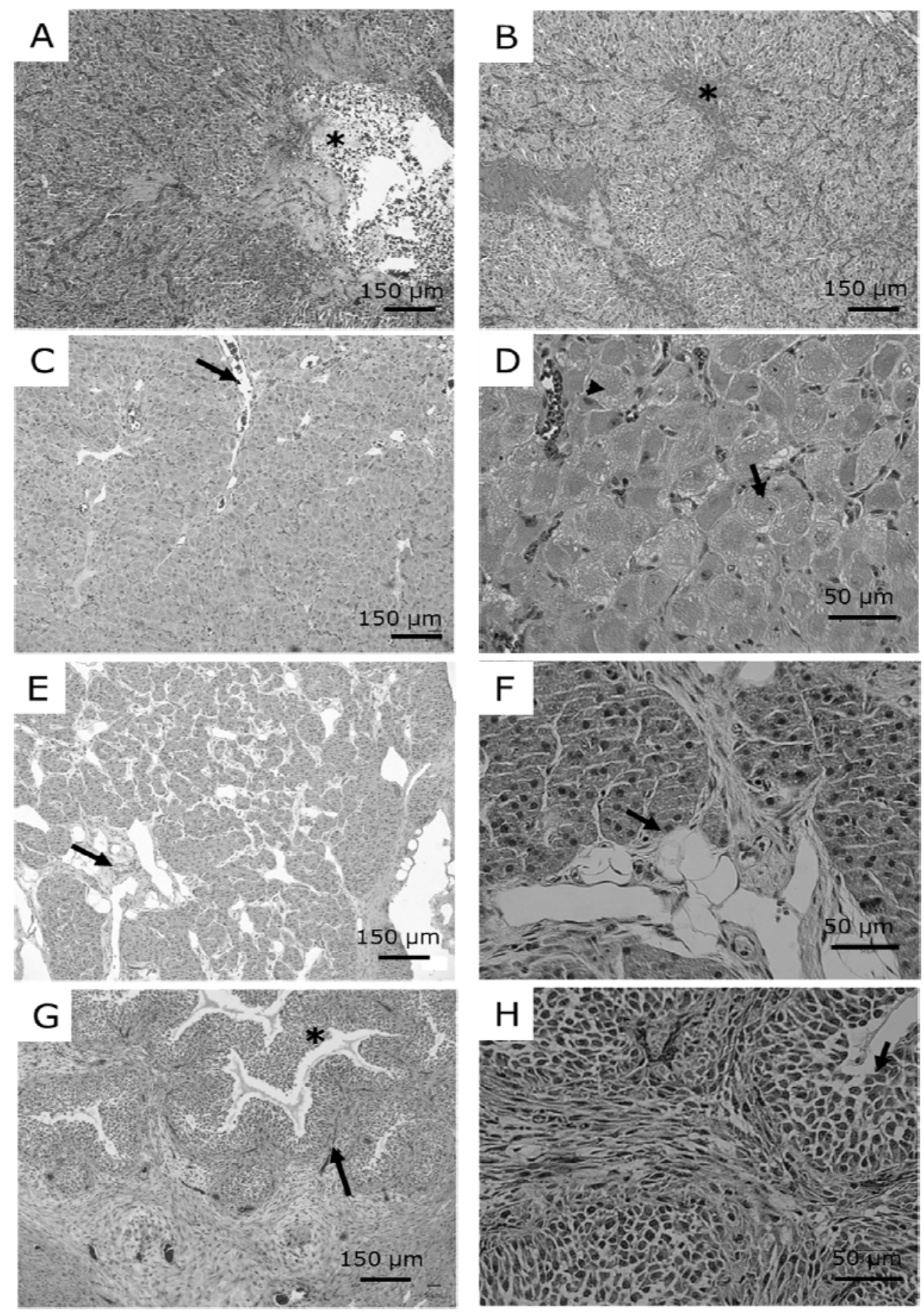

Figure 3. Corpora lutea of peccary during the phases of the estrous cycle. A- corpus hemorrhagicum (G1 -3 days p.o.). Central coagulate (*). B- CH with smaller coagulates in the center of each lobule (*). C- mature CL (G2- D12 p.o.). Large and long blood vessels in the interlobule septum $(\rightarrow)$. D- mature CL with large luteal cells (LLC) with vacuolized cytoplasm and spherical nuclei with nucleoli $(\rightarrow)$ and small luteal cells (SLC) with low vacuolized cytoplasm and heterochromatic nucleus (arrow head). E- Early regression CL (G3- D18 p.o.). Observe fragmentation of the luteal lobules and invasion of the conjunctive tissue $(\rightarrow)$. F- In early regression CL, luteal cells were more elongated with heterochromatic nucleus $(\rightarrow)$. G- Late regression CL (G4- D22 p.o.). Observe atrophied luteinic lobules $(*)$ with intense invasion of the connective tissue $(\rightarrow)$. H - Late regression CL with fusiform luteal cells $(\rightarrow)$. HE staining. 
The vascular density of the peccary's CL was affected by the estrous cycle phases (Figure 4). Statistical analysis evidenced an extremely significant difference of the variables among the groups under analysis $(\mathrm{P}<0.0001)$. Data showed a two-fold increase in the density of vascular volume $(\mathrm{Vv})$ from Group 1 to Group 2. There was a 58\% decrease between Groups 2 and 3, with the lowest Vv in Group 4.

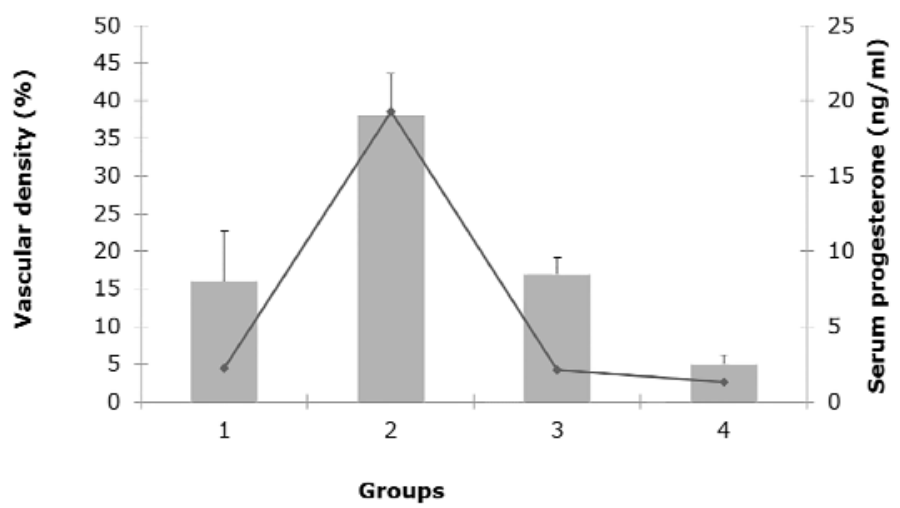

Vascular density $\rightarrow$-Serum progesterone

Figure 4. Vascular density of the corpus luteum and serum concentration curve of progesterone of peccaries throughout the estrous cycle.

The serum concentration of progesterone also varied throughout the estrous cycle (Figure 4). A higher concentration of progesterone was detected in Group 2, which confirmed maximum secretion activity of the animals' CL. A significant decrease occurred from Group 2 to Group 3 in the production of the hormone which indicated the group's functional luteolysis.

There was a significant co-relationship between measurements of the CL by ultrasonography and by post-mortem morphometry with the serum concentration of progesterone. A high corelationship should be underscored between length and width obtained by ultrasonography, and width, measured by the calipers, with the progesterone levels (Table 4).

\section{DISCUSSION}

The morphology of peccary's ovaries varied during the estrous cycle particularly due to the formation and regression of the corpora lutea on the surface of the organ. The corpora lutea caused the ovaries to have a bunch-of-grapes shape since profuse follicles were not found on the species's ovary surface (Figure 3), similarly to those reported by Mayor et al. (2006a). The most significant co-relationships between weight and length of the ovaries and of the corpora lutea in the current analysis $(r=0.66, p=0.0019 ; \mathrm{r}=0.52$, $\mathrm{p}=0.0191$, respectively) evidence a strict relationship between ovary and corpora lutea anatomy in the species.

Length and width of ovaries in the animals assessed in the current assay were greater than those described by Mayor et al. (2006b) for peccaries of the Peruvian Amazon. These authors reported significant differences in the ovary's length among the phases of the estrous cycle, very different from current results that revealed a highly significant influence on length and weight $(\mathrm{P}<0.001$, Table 1). These authors may have taken measurements without considering the corpora lutea projected on the ovaries' surface. The fact justifies the lack of significant results on the estrous cycle and in rates which were lower than current description.

The number of corpora lutea per animal corresponds to ovulation rate since each corpus luteum corresponds to an ovulated mature follicle. Mayor et al. (2006a) reported an average ovulation rate of $2.1 \pm 0.6$ corpora lutea/female peccary in 16 animals, lower than the rate 
(10 - 24) for domestic (Gordon, 1997) and wild (4 - 6) pigs. According to Mayor et al. (2006a), low ovulation rate in peccaries would be a biological impairment in the proliferation of the animal. Current analysis shows that the average number of corpora lutea per animal in all groups

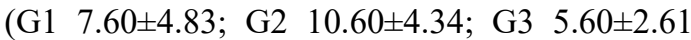
and G4 7.60 \pm 2.88 ) was higher than averages by Mayor et al. (2006a). Higher rates are perhaps due to the use of equine chorionic gonadotropin (eCG) in the treatment of estrous synchronization. The hormone acts similarly to the hypophyseal gonadotropin FSH and LH and may have contributed towards the maturation and ovulation of a greater number of follicles in the animals in the current analysis. This result was highly significant since it somewhat demonstrated the possibility that the hormone could be used in future protocols of the species's superovulation.

Peccary CL measurements revealed that a significant growth occurred up to day 12 p.o. Growth exceeded half of the estrous cycle on average during $21 \pm 5.7$ days, as described by Silva et al. (2011) for animals bred under the same conditions. Progressive decrease was reported close to day 16 p.o. and culminated in lower size and weight rates at 22 days p.o. Statistical analysis revealed that weight, length and width of the corpora lutea were also significantly affected by the estrous cycle phase $(\mathrm{P}<0.001$, Table 3$)$. The above result has been expected since the measurements of the organ frequently estimate the stage of the estrous cycle and the luteal functional activity (Ferreria-Dias et al., 2006; Papa et al., 2007; Nascimento et al., 2003; Miranda-Moura et al., 2010). Current rates were once again higher when compared to the diameter and volume of peccaries' CL described by Mayor et al. (2006a), perhaps due to the difference in the diet's energy rates taken by the animals favoring weight gain and thus their reproduction. A similar argument was employed by Mangini (1999) to explain the higher measurements of the reproducing organs of the wild pig. Unfortunately, Mayor et al. (2006a) failed to give any information on the animals' diet during the experiment. Another explanation for bigger corpora lutea in animals in the current study would be the mitotic effect of the eCG on the luteinic cells, recently provided by Rigoglio et al. (2013) when they studied the corpora lutea of cows treated by the same hormone.
Serum concentrations of progesterone in the different phases of the estrous cycle varied between 1.33 and $19.26 \mathrm{ng} / \mathrm{mL}$. Although compatible to those described for wild pigs by Mangini (1999) and Mauget et al. (1997), rates were lower than those for peccaries described by Mayor et al. (2006b), which ranged between 4.3 and $30.8 \pm 4.9 \mathrm{ng} / \mathrm{mL}$ from day 3 to 11 post estradiol peak. The difference may be due to the sensitiveness of the methods used in hormone dosages. Mayor et al. (2006b) used the immunoenzymatic method of competitive chemo-luminescence, which is more sensitive than solid phase RIA used in the current assay and in those by Mangini (1999) and Mauget et al. (1997). The above may explain the compatible rates. However, the behavior of progesterone concentrations and their peak day in the current assay were similar to those described by Mayor et al. (2006b).

Measurement variations of the corpora lutea during the estrous cycle demonstrated the functional activity of the organ, which, in this case, was assessed by progesterone concentration. This fact has been confirmed by the highly significant co-relationships between measurements and progesterone concentration (Table 4). Measurements by ultrasonography test showed highly significant co-relations with progesterone concentrations (Table 4), corroborated by Siqueira et al. (2009). The above shows the relevance of ultrasonography tests in the evaluation of the functional activity of the corpus luteum.

Vascular density is a very important parameter that reveals the vascularization of the tissue and, consequently, the level of blood perfusion (Asahara et al., 1995). Vascular density is often assessed in the corpus luteum since it is a gland whose function is closely related to vascularization (Gaytan et al., 1999). In spite of studies on the variations in lutein vascular density during the estrous cycle in other species (Moura et al., 2003; Miranda-Moura et al., 2010), the current analysis on the peccary features is the first investigation and is a pioneering endeavor.

The current study demonstrates that besides the macro and microscopic modifications of the luteal structure, other changes occurred in the vascular network of the peccaries' corpus luteum 
throughout the estrous cycle, which showed the organ's functional activity. High concentrations of $\mathrm{P}_{4}$ in peccaries occurred on day 12 p.o. and confirmed the mature CL phase in which a higher vascular density was also reported. Increase in blood supply and in $\mathrm{P}_{4}$ secretion, also at this stage, were reported in other species (Jablonka-Shariff et al., 1993; Papa et al., 2007). A decrease in $\mathrm{P}_{4}$ concentration in the current study foregrounded the occurrence of functional luteolysis on day 18 p.o., followed by structural luteolysis and culminated in corpus albicans formation when the concentration of the hormone decreased to basal levels (Neuvians et al., 2004). The decrease in $\mathrm{P}_{4}$ secretion coincided with a reduction of vascular density on day 16 p.o. Similar results were previously provided for goats, cows and buffaloes (Moura et al., 2003; Papa et al., 2007; Miranda-Moura et al., 2010).

Several research works reported that these changes in the production of progesterone by the CL occurred because of alterations in the steroidogenic capacity of luteal cells affected by gonadotropin and other hormones, such as $\mathrm{PGF}_{2 \alpha}$ and ocytocin (Milvae et al., 1996). It may be concluded that a greater number of CL may explain the variations in progesterone levels in peccaries. However, the total number of CL and progesterone concentration did not have any significant co-relationship $(\mathrm{r}=0.3156 ; \mathrm{p}=$ 0.6653 ), contrastingly to the highly significant co-relationships between vascular density and progesterone level $\left(\mathrm{VvP}_{4}-\mathrm{r}=0.6437 ; \mathrm{P}<0.0001\right)$. This result confirms the dependence of CL on a blood rate proportional to the performance of its function.

\section{CONCLUSION}

Corpora lutea of the collared peccary underwent morphological changes throughout the estrous cycle that may estimate stages of the estrous cycle in the species. The luteal vascular density may influence progesterone production, which may serve as a functional parameter to evaluate the organ.

\section{ACKNOWLEDGEMENTS}

The authors would like to thank the National Council for Scientific and Technological Development (CNPq) for the scholarship grant.

\section{REFERENCES}

ACOSTA, T.J.; MIYAMOTO, A. Vascular control of ovarian function: ovulation, corpus luteum formation and regression. Anim. Reprod. Sci., v.82/83, p.127-140, 2004.

ASAHARA, T.; BAUTERS, C.; ZHENG, L.P. et al. Synergistic effect of factor of growth of vascular endothelial and fibroblast growth basic factor in angiogenesis in alive. Circulation, v.92, p.11365-11371, 1995.

BERTAN, C.M.; BINELLI, M.; MADUREIRA, E.H. et al. Mecanismos endócrinos e moleculares envolvidos na formação do corpo lúteo e na luteólise: revisão de literatura. Braz. J. Vet. Res. Anim. Sci., v.43, p.824-840, 2006

FERREIRA-DIAS, G.; BRAVO, P.P.; MATEUS, L. Microvascularization and angiogenic activity of equine corpora lutea throughout the estrous cycle. Domest. Anim. Endocrinol., v.30, p.247-259, 2006.

GAYTAN, F.; MORALES, C.; GARCIAPARDO, L. et al. A quantitative study of changes in the human corpus luteum microvasculature during the menstrual cycle. Biol. Reprod., v.60, p.914-919, 1999.

GORDON, I. Controlled reproduction in pigs. New York: CAB International, 1997. 288p.

JABLONKA-SHARIFF, A.; GRAZUL-BILSKA, A.T.; REDMER, D.A. et al. Growth and cellular proliferatin of ovine corpora lutea throughout the estrous cycle. Endocrinology, v.133, p.18711879, 1993.

MANGINI, P.G. Estudo dos níveis séricos de progesterona e estradiol e da estrutura do trato genital feminino de queixada (Tayassu pecari Link, 1795). 1999. 77f. Dissertação (Mestrado em Ciências Veterinárias) - Universidade Federal do Paraná, Curitiba, PR.

MAUGET, R.; FEER, F.; HENRY, O. et al. Hormonal and behavioural monitoring of ovarian cycles in peccaries. In: INTERNATIONAL SYMPOSIUM ON PHYSIOLOGY AND ETHOLOGY OF WILD AND ZOO ANIMALS, 1., 1997, Berlin. Anais...Berlin: [s.n.], 1997. Supl.2, p.145-149. (Abstract). 
MAYOR, P.; FENECH, M.; BODMER, R. et al. Ovarian features of the wild collared peccary (Tayassu tajacu) from the northeast Peruvian Amazon. Gen. Comp. Endocrinol., v.147, p.268275, 2006a.

MAYOR, P.; GUIMARÃES, D.A.; LOPEZGATIUS, F. et al. First postpartum estrus and pregnancy in the female collared peccary (Tayassu tajacu) from the Amazon. Theriogenology, v.66, p.2001-2007, 2006b.

MILVAE, R.A.; HINCKLEY, S.T.; CARLON, J.C. Luteotropic and luteolytic mechanisms in the bovine corpus luteum. Theriogenology, v.45, p.1327-1349, 1996.

MIRANDA-MOURA, M.T.M.M.; FONSECA, V.U.; SILVA, N.B. et al. Morphological features and vascularization study of caprine cyclic corpus luteum. Pesqui. Vet. Bras., v.30, p.351357, 2010.

MOURA, C.E.B.; CAMPOS, D.B.; PEREIRA, F.T.V. et al. Density of Corpus luteum from superovaluted and control buffalo cows. Acta Microsc., v.12, p.43-44, 2003.

NASCIMENTO, A.A.; PINHEIRO, N.L.; SALES, A. et al. Correlação morfométrica do ovário de fêmeas bovinas em diferentes estádios reprodutivos. Braz. J. Vet. Res. Anim. Sci., v.40, p.126-132, 2003.

NASCIMENTO, I.M.R.; SOUSA JÚNIOR, A.; CHAVES, R.M. et al. Sincronização de estro em cabras utilizando diferentes progestágenos. Rev. Cient. Prod. Anim., v.11, p.46-54, 2009.

NEEDLE, E.; PIPARO, K.; COLE, D. et al. Protein kinase A-independent cAMP stimulation of progesterone in luteal cell model is tyrosine kinase dependent but phosphatidylinositol-3kinase and mitogen-activated protein kinase independent. Biol. Reprod., v.77, p.147-155, 2007.
NEUVIANS, T.P.; BERISHA, B.; SCHAMS, D. Vascular endothelial growth factor (VEGF) and fibroblast growth factor (FGF) expression during induced luteolysis in the bovine Corpus luteum. Mol. Reprod. Dev., v.67, p.389-395, 2004.

NOWAK, D.M.; PARADISO, J.L. Walkeris mammals of the world. 2.ed. Baltimore: The Hopkins University Press, 1983. 2015p.

PÉREZ-OLVERA， O.; BALDERAS， S.A.; MARTÍNEZ, H.A.R. Revisión de los métodos estereológicos y su aplicación en biología celular. Patología, v.50, p.63-71, 2012.

PAPA, P.C.; MOURA, C.E.B.; ARTONI, L.P. et al. VEGF system expression in different stages of estrous cycle in the corpus luteum of nontreated and superovulated water buffalo. Domest. Anim. Endocrinol., v.33, p.379-389, 2007.

RIGOGLIO, N.N.; FÁTIMA, L.A. HANASSAKA, J.Y. et al. Equine chorionic gonadotropin alters luteal cell morphologic features related to progesterone synthesis. Theriogenology, v.79, p.673-679, 2013.

SILVA, A.R.; SILVA, M.A.; LIMA, G.E. et al. Estratégias para a conservação do germoplasma de catetos (Tayassu tajacu Linnaeus, 1758) no bioma caatinga. Rev. Bras. Reprod. Anim., v.35, p.118-123, 2011.

SIQUEIRA, L.G.; TORRES, C.A.; AMORIM, L.S. et al. Interrelationships among morphology, echotexture, and function of the bovine corpus luteum during the estrous cycle. Anim. Reprod. Sci., v.115, p.18-28, 2009. 